\section{B A Institute of \\ YK Business Administration \\ 六下 \\ Karachi \\ Leadership and Ideas for Tomorrow}

\section{Business Review}

Volume 1 Issue 1

July - December 2006

7-1-2006

\title{
Book Review of: Barbara D. Metcalf, Islamic Contestations: Essays on Muslims in India and Pakistan
}

\section{Bettina Robotka}

Institute of Business Administration, Karachi, Pakistan

Follow this and additional works at: https://ir.iba.edu.pk/businessreview

Part of the Religion Commons

\section{c) (i)}

This work is licensed under a Creative Commons Attribution 4.0 International License.

\section{Recommended Citation}

Robotka, B. (2006). Book Review of: Barbara D. Metcalf, Islamic Contestations: Essays on Muslims in India and Pakistan. Business Review, 1(1), 198-200. Retrieved from https://doi.org/10.54784/ 1990-6587.1106

This article is brought to you by iRepository for open access under the Creative Commons Attribution 4.0 License and is available at https://ir.iba.edu.pk/businessreview/vol1/iss1/18. For more information, please contact irepository@iba.edu.pk. 


\title{
BOOK REVIEW
}

\author{
Barbara D. Metcalf \\ Islamic Contestations. \\ Essays on Muslims in India and Pakistan \\ (Oxford University Press, 2004) \\ ppx 365, map, illustrations, index, Rs. 595
}

$\mathrm{T}$

his publication of the Oxford University Press is a collection of articles and essays

which had been written by the well-known professor of Islamic history Barbara D. Metcalf during the last twenty-five years on the subject of Muslims in the South Asian subcontinent. They had been published in a variety of journals and books before they came together in this remarkable collection testifying about the persisting interest and work done by Barbara Metcalf on the subject.

There are 15 essays which are grouped together in four main categories. The first group deals with responses of Indian ulema to modern developments in the late 19th and early 20th century in British-India. The first article is on the madrassah of Deoband, the topic of Metcalf's doctoral thesis. It had been originally published in 1978 and is of considerable interest even today. Since much hue and cry has been raised lately about madrassahs, the author chooses this as her entry point. Beginning with religious education imparted to Muslims in different madrassahs down the ages, she tries to dispel the misconceptions about these seats of learning. In the course of her analysis she brings a very important fact to the readers notice: the fact that the so-called traditional Deobandi School, together with being firmly rooted in the revivalist thought of Shah Waliullah, was very much modern in its character and organizational set-up. Above that, it did share a common intellectual basis with the "modern" Aligarh School in the Indian revivalist thought of the 18th century on which both were drawing their intellectual roots. On the basis of Metcalf's finding, it is getting quite clear that the difference between Deoband and Aligarh is not so much the missing modernity of the one but the Westernization of the other which was firmly rejected by the Deobandis. A second essay on two religious rulings Deobandi fatwas of the late 19th century exposes the same revivalist spirit of the ulema who were recommending to go back to the Qur'an and the Hadith directly without consulting the commentaries of the four established schools of law in one case and apply their own reasoning and in the other pleading to treat British-India as Dar-ul Islam, a country where Muslims could profess their religion freely and where there was no need to migrate to another place. Both fatwas are ample proof for the reasonable attitude of Deobandi ulema towards the problems of their time. The last essay of this section deals with another representative of the Deobandi thought, Maulana Muhammad Zakariyya Kandhlawi (d. 1982).

The second section of the current publication illustrates the variety of Muslim cultural and political life in British-India prior to 1947. It includes an essay on the role of women as it has been depicted in the writings of three main groups of Muslim reformers: 
ulema, westernized elite Muslims and Islamists. Another two essays deal with Hakim Ajmal Khan, an Indian Muslim nationalist and the last one focuses on the questions of nationalism, modernity and Muslim identity during the period between the two World Wars. The most interesting thing in this section is the author's findings about the role model for women in the different groups of Muslim reformers which had been originally published as early as 1982 i.e., more than twenty years ago. The women question being a hot issue until today it seems hardly anyone of the players in the women's movement or the writers on gender issues seem to have ever taken notice of Metcalf's conclusions at which she arrived after having studied and translated vernacular pamphlets and books related to the women's issue, the most important being Maulana Ashraf Ali Thanvi's Bihishti Zewar. Analyzing this guidebook for young girls and women as to what virtues were recommended by the Deobandi Alim at the beginning of the 20th century, she writes: "For all that, the teachings of the ulema, grounded in Qur' an and Hadith, were striking in the significant respect that they did not elaborate a difference between women and men. There was of course the crucial difference of role that placed women squarely in the home. But in terms of essential nature and potential, women and men were regarded as one." (p. 105) And later she writes: "The conclusive evidence that Thanavi enjoined a single standard of behavior for women and men was his response when he was asked to write a companion guide, a Bihishti Zewar directed to men. He replied that the existing book would serve perfectly well - he simply added an appendix describing practices such as the community prayer specific to men." (p. 106) The author rightly observes that there would have been hardly any European or American publication on women available in the early days of the 20th century which would evenly be recommended as a proper guide for men. It took the Western women half a century and a struggle which at times has been reminding a "holy war against men" to prove their equal abilities and get them more or less recognized by their male counterparts. Unfortunately, this remarkable attitude of Thanavi and likeminded ulema got submerged in the "civilizing mission" of the British who implanted together with all the other notions of European modernity their ideas about gender, gender relations and women's equality into British-India and created a westernized elite in Aligarh at that time and in the Pakistani and Western universities today who fully subscribe to that model. Few authors, like B. Metcalf, have been sensitive enough not to follow that trend but to have a close and unbiased look into what really was going on in the Indian Muslim community and to draw independent conclusions.

The third group of essays includes an article on religious nationalism in India, two on Islam and interpretations of Islam in Pakistan and one on the ideology of Deobandi activist movements like Tablighis and their respective attitudes towards state, politics and political power structures.

The last section titled "Islam, society and the imagination of the self" carries four articles. They deal with self-reflection of Muslims in India and Pakistan and their search for identity. The chapter starts with an essay on Iqbal's views on the self (ego) as expressed in his famous poem about the mosque of Cordoba which serves as a 
symbol for the need of Muslim awakening. It proceeds with an interpretation of South Asian Muslim accounts about their pilgrimages. The last article in this collection is an essay on the biographies of three historical figures: A Mughal queen, a French adventurer in the princely state of Awadh in Northern India and a Muslim nationalist. Again, the article shows the self-reflections of individuals in an Indian surrounding.

The re-publication of these essays as "Islamic Contestations" by the Oxford University Press is a very laudable and timely effort from two points of view. In the first place, it is a document of the long-term and sustained effort of a prominent American scholar writing on an often neglected and even controversial subject: Islam and Muslims in India and Pakistan. The in-depth knowledge she provides about subjects like the Deoband movement. Muslim madrassah education, Muslim identity, role and place of Muslim women in society and many more very specialized and well-researched topics are an ample example of her scholarly interest in the subject over almost a professional lifetime. In a time when Western attitudes are under severe critique, it is timely to remember that there is no such unified "Western" attitude and that some of the "Western" scholars have made a real and sustained effort to understand and analyze such controversial subjects as Islam, and Islamic movements and ideologies happen to be. However, the insights and solutions which were published years and decades before have not entered into the mainstream discourse until today, neither in the scholarly nor in the public field of discussion. Therefore, the reproduction of these essays collectively in one volume may be a fresh effort towards the same objective: "to challenge the often negative stereotypes that are current" (Jacket) about Islam and Islamic movements, about Muslim women and so many others.

"Whether weak or strong, culture has a powerful influence throughout an organization; it affects practically everything - from who gets promoted and what decisions are made to how employees dress and what sports they play. Because of this impact, culture has a major effect on the success of a business."

Deal and Kennedy, Corporate Cultures 